\title{
Stromal Fat Content of the Parathyroid Gland - A Study on 60 Autopsy Cases
}

\author{
Nurunnabi $\mathrm{ASM}^{1}$, Mahbub S ${ }^{2}, \operatorname{Ara~}^{3}$
}

\begin{abstract}
Controversies prevail in literatures about fat content of the parathyroid glands and no histological study was done before to observe the change with increasing age in a Bangladeshi population. The aim of the study was to determine the percentage of stromal fat in the parathyroid glands in different age in a Bangladeshi population. This cross-sectional, descriptive study was done in the Department of Anatomy, Dhaka Medical College, Dhaka, from January to October 2011. A total of 207 post mortem parathyroid glands of were collected from 60 Bangladeshi people of different age (unclaimed autopsied dead bodies, within 24-36 hours of death without any sign of putrefaction). The samples were divided into three groups i.e. A (11-30years), B (31-60years), and $C$ (61-90years). Tissue blocks of the parathyroid gland were fixed in 10\% formol saline, cut at $5 \mu \mathrm{m}$ thickness and stained with routine Harris' Haematoxylin and Eosin $(H \& E)$ stain. From each age group 20 best prepared slides were taken. The proportion of fat of the parathyroid gland was determined with the point counting Zeiss-I integrating eyepiece under the light microscope. The data were collected from the histological study and statistical analyses were done by one-way ANOVA test. All the statistical analyses were done by using SPSS 13.0 version. The mean amount of stromal fat was found $35.65 \pm 1.63 \%, 42.56 \pm 1.27 \%$, and $46.38 \pm 1.54 \%$ in group $A, B$ and $C$ respectively. The differences among the groups were statistically significant (P 0.001). The percentage of stromal fat of the parathyroid gland was found to increase with age in Bangladeshi people.
\end{abstract}

Key words: Stroma, fat content, parenchyma, parathyroid gland.

\section{Introduction}

The parathyroid glands are essential for the survival of the human being. Normal parathyroids consist not only of parenchymal cells and stroma but also of fat tissue, varying with the age of the individual ${ }^{1}$. The parenchyma of the parathyroid glands consists of three types of cells; the chief cell, the oxyphil cell and water-clear cell, which

\footnotetext{
1. Corresponding author:

Dr. Abu Sadat Mohammad Nurunnabi

Lecturer, Department of Anatomy

Dhaka Medical College, Dhaka

E-mail: shekhor19@yahoo.com

2. Dr. Sabiha Mahbub

Associate Professor, Department of Anatomy

Shahabuddin Medical College, Dhaka.

3. Dr. Shamim Ara

Professor and Head, Department of Anatomy

Dhaka Medical College, Dhaka.
}

are embedded in fibrous stroma containing blood vessels with varying amounts of fat cells, depending on the patient's age and amount of body fat ${ }^{2,3}$. According to standard texts of pathology, the fat content of normal parathyroid glands varies between $40 \%$ and $70 \%$; $50 \%$ is generally accepted as the average normal ratio of stromal fat to parenchyma $\mathrm{a}^{4,5}$. In general, the principle is sound, and an increase in parenchyma with a decrease in stroma does indicate hyperplasia, but the point of issue is how much fat is normal. In the microscopic evaluation of parathyroid glands, many pathologists rely on the percentage of fat to determine whether a gland is hyperplastic or normal, ${ }^{6-10}$ using a figure of $50 \%$ as representing the ratio of fat to parenchyma in the normal gland ${ }^{4}$. However, some researchers agreed that percentage fat may not be used as an index of hyperplasia ${ }^{4,11-14}$ through a microscopic evaluation. Hence, controversies still prevail in literatures about fat content of the parathyroid glands and no histological study was done before to observe the change in a Bangladeshi population with increasing age. The aim of the study was to determine the percentage of stromal fat in the parathyroid glands in different age in a Bangladeshi population.

\section{Materials and Methods}

A cross-sectional, descriptive study was done in the Department of Anatomy, Dhaka Medical College, Dhaka, from January to October, 2011, to determine the percentage of stromal fat in the parathyroid glands in different age in a Bangladeshi population. A total of 207 post mortem parathyroid glands of were collected from 60 Bangladeshi people of different age. The samples were collected from the unclaimed dead bodies which were under examination in the Department of Forensic Medicine of Dhaka Medical College, Dhaka. All the samples were collected within 24-36 hours of death without any sign of putrefaction, from medicolegal cases excluding hanging, poisoning, any cutting or crushing injury to neck region and known case of parathyroid disease. All the collected samples were brought to the Department of Anatomy and preserved in 10\% formol saline for further study. This research work was approved by the Ethical Review Committee of Dhaka Medical College, Dhaka.

Grouping of the sample: The samples were divided into three groups i.e. A (11-30 years), B (31-60 years), and C (61-90 years), according to Panijian et al. $(2006)^{15}$.

Preparation of the slide: Tissue blocks of the parathyroid gland were fixed in $10 \%$ formol saline in a plastic container. The tissues were washed in running tap water, dehydration was done with ascending grades of alcohol, 


\section{ORIGINAL ARTICLE}

cleared with xylene, infiltrated and embedded in paraffin. Paraffin blocks were cut at $5 \mu \mathrm{m}$ thickness and were stained with routine Harris' Haematoxylin and Eosin ( $\mathrm{H} \&$ E) stain.

Microscopic measurement: The light compound microscope which was used for the microscopic measurement was OLYMPUS CHB, made in Tokyo, Japan and studied at low magnification ( X 10 objective, X 10 eyepiece).

Estimation of percentage of fat: The parenchyma of the parathyroid glands consists of three types of cells named chief cells, the oxyphil cells and water-clear cells. The stroma includes fat, connective tissue and vessels ${ }^{2}$ (Fig. 1).

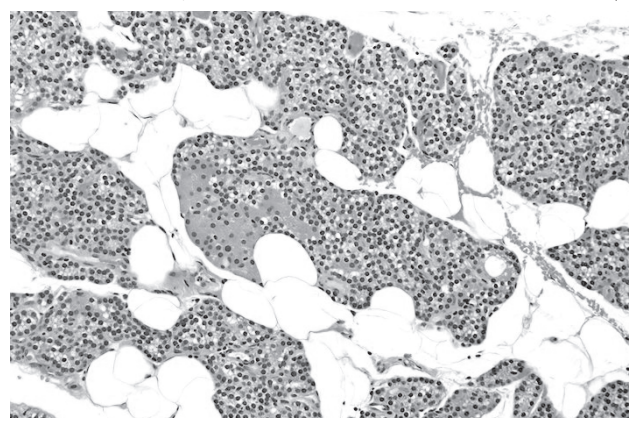

Fig. 1. Photomicrograph of the human parathyroid gland, taken from group A (11-30 years). The white round structures are fat cells (Ч100 magnification) (H \& E stain).

From each age group 20 best prepared slides were taken. The proportion of structural components of the parathyroid gland was determined with the point counting technique as described by Laga, Driscoll \& Munro $(1973)^{16}$. Point counting Zeiss-I integrating eyepiece was prepared in a transparent plastic sheet and was placed into the eyepiece. This eyepiece contains a point network of 25 points spaced at $70 \mu \mathrm{m}$, arranged within a circle which is regarded as the counting field. Then the counting was done. The position of each point falling on any structural component was recorded for each field. Then the eyepiece was rotated $90^{\circ}$ keeping the field constant. Again the position of the each point was recorded. Thus 50 points were recorded for each field. Five such fields or 250 points were studied on each section. The total number of points fitting each component was summed up and expressed as a percentage of the total number of points fitting the structural component of parathyroid glands. This percentage represents the proportion of fat in stroma.

Statistical analysis: The data collected from the histological studies were processed and statistical analyses were done by one-way ANOVA test. All the statistical analyses were done by using the SPSS 13.0 version.

\section{Results}

In the present study, the mean amount of stromal fat of the parathyroid gland was found $35.65 \pm 1.63 \%$, $42.56 \pm 1.27 \%$, and $46.38 \pm 1.54 \%$ in group $\mathrm{A}, \mathrm{B}$ and $\mathrm{C}$ respectively. The differences among the groups were statistically significant $(\mathrm{P}<0.001)($ Table-I).

Table-I: Fat contents of stroma of parathyroid gland in different age group

\begin{tabular}{lll}
\hline Age group & Amount of fat $(\%)$ & P value \\
\hline A & $35.65 \pm 1.63$ & A vs B \\
$(\mathrm{n}=20)$ & $(33.05-37.38)$ & $<0.001^{* * *}$ \\
\hline $\mathrm{B}$ & $42.56 \pm 1.27$ & A vs C \\
$(\mathrm{n}=20)$ & $(41.16-44.05)$ & $<0.001^{* * *}$ \\
\hline $\mathrm{C}$ & $46.38 \pm 1.54$ & B vs C \\
$(\mathrm{n}=20)$ & $(44.74-48.07)$ & $<0.001^{* * *}$ \\
\hline
\end{tabular}

Figures in parentheses indicate range. Comparison in between different age groups were done by One way ANOVA (PostHoc), ${ }^{* * *}=$ significant.

Group A: 11-30 years

Group B: 31-60 years

Group C: 61-90 years

\section{Discussion}

In previous studies, estimation of the parenchymal cell mass of parathyroid glands has been based on a microscopically ocular evaluation of the distribution of the two main glandular components, i.e. parenchymal cells and fat tissue ${ }^{3,5}$. Gilmour \& Martin $(1937)^{3}$, in their basic estimation of parathyroid parenchymal cell mass, used only one section as representative of the whole gland. Nor did these authors consider the difference in shrinkage between the two glandular components during the histotechnical preparation. They used approximated values of tissue-specific density (fibrous tissue and parenchymal cells $=1.1$ and fat cells $=0.9 \mathrm{~g} / \mathrm{ml})$, which are clearly disaccordant with the values Grimelius et al. $(1976)^{11}$ obtained by measurement (parenchymal cells = 1.06 and fat cells $=0.93 \mathrm{~g} / \mathrm{ml}$ ). The proportion of stromal fat cells to parenchymal cells in 100 normal parathyroid glands was determined by the image analyzing computer technique. The parathyroid glands were resected at the time of thyroidectomy in 86 patients with thyroid tumors. None of the patients had any evidence of parathyroid dysfunction preoperatively. In the histologic sections of the parathyroid glands, the average percentage of stromal fat cell content was $38 \%$. The percentage of stromal fat cells was correlated with the age and the body constitution of the patients, but the percentages of fat cells varied widely among glands in the given age and body constitution ranges. Dekker, Dunsford \& Geyer (1979) ${ }^{12}$ stated that the lack of functional specificity of change in stromal fat, whereas, alteration in parenchymal fat appears to be a better anatomical register of normal or abnormal parathyroid function. They evaluated the stromal and parenchymal fat of the parathyroid glands of 33 adult patients who died with no known hormonal abnormalities. Stromal fat was found much less than $50 \%$, i.e. less than $10 \%$, in the majority of cases, while parenchymal fat was ample in all cases. Dufour \& Wilkerson $(1982)^{13}$ reported 
an average fat content of $17 \%$. Their figure is deceptively low because their percentage includes only the adipose part of the stroma and not all of it, and the inverse percentage does not represent parenchyma, as customarily viewed by pathologists. Saffos, Rhatigan \& Urgulu (1984) ${ }^{14}$ did an autopsy study of 138 glands from 38 adults without evidence of hyperparathyroidism and found less adipose tissue in the glands of many normal adults than had been reported earlier. They also suggested that a distinction between normal and early hyperplasia cannot be made, especially if it is solely based on the stromal adipose tissue content of the gland. Ghandur-Mnaymneh et al. (1986) studied a total of 166 subjects where it was found that fat was unevenly distributed throughout the gland, and its amount was highly variable, ranging between 0 and $90 \%$, with a mean of $26 \%$ for white subjects and $24 \%$ for black subjects in both series. The distribution of the fat within the gland was very uneven, with one part being richly parenchymatous, while the remaining part consisted predominantly of fat cells. This uneven distribution did not correlate with the percentage of fat content or the size of the gland. According to Young et al. ${ }^{17}$, adipose tissue comprises $25-40 \%$ of normal parathyroid gland tissue.

In our study, stromal fat of the parathyroid gland was found to increase with advancing age; however, it ranged from $33.05 \%$ to $48.07 \%$. The findings of the present study were similar to the findings of Gilmour \& Martin ${ }^{3}$, Grimelius et al. ${ }^{11}$ and Young et al. ${ }^{17}$; however, the findings were slightly greater than that of the average fat contents as described by Ghandur-Mnaymneh et al. ${ }^{4}$ and Dufour \& Wilkerson $^{13}$, and much more greater than that of Dekker, Dunsford \& Geyer ${ }^{12}$ and Saffos, Rhatigan \& Urgulu ${ }^{14}$. The differences among those research results may be attributable to differences in racial distribution and measurement techniques.

The percentage of stromal fat of the parathyroid gland was found to increase with advancing age in Bangladeshi people. To the best of our knowledge, this is the first ever experiment in our country to estimate the fat content of the parathyroid gland. The results of the present study can be used as a standard reference for the fat content of the parathyroid glands of Bangladeshi people and to determine the abnormal evidences in pathological cases. However, further studies with more samples and high technical back up, e.g. computerized stereotechnique, are recommended.

\section{References}

1. Obara T, Fujimoto Y, Aiba M. Stromal fat content of the parathyroid gland. Endocrinol Jpn 1990;37(6):901-5.

2. Berkovitz BK. ed. Neck and upper aero-digestive tract. In: Standring $\mathrm{S}$, Ellis $\mathrm{H}$, Healy JC, Johnson D, Williams A, Collins P, et al. eds. Gray's anatomy: the anatomical basis of clinical practice. 39th ed. London: Elsevier Churchill Livingstone; 2005: p.564-5.
3. Gilmour JR, Martin WJ. The weight of the parathyroid glands. J Pathol Bacteriol 1937;44:431-62.

4. Ghandur-Mnaymneh L, Cassady J, Hajianpour MA, Paz J, Reiss E. The parathyroid gland in health and disease. Am J Pathol 1986;125(2):292-9.

5. Gilmour JR. The normal histology of the parathyroid glands. J Pathol Bacteriol 1939;48(1):187-222.

6. Roth SI. Pathology of the parathyroids in hyperparathyroidism. Arch Pathol 1962;73:495-510.

7. Straus FH, Paloyan E. The pathology of hyperparathyroidism. Surg Clin North Am 1969;49(1):27-42.

8. Block MA, Frame B, Jackson CE, Parfitt AM, Horn RC Jr. Primary diffuse microscopical hyperplasia of the parathyroid glands: surgical importance. Arch Surg 1976;111(4):348-54.

9. Kay S. The abnormal parathyroid. Hum Pathol 1976;7(2):127-38.

10. Harrison TS, Duarte B, Reitz RE, Princenthal R, Seaton JF, Badder EM, et al. Primary hyperparathyroidism: four- to eight-year post-operative follow-up demonstrating persistent functional insignificance of microscopic parathyroid hyperplasia and decreased autonomy of parathyroid hormone release. Ann Surg 1981;194:429-37.

11. Grimelius L, Ejerblad S, Johansson H, Werner I. Parathyroid adenomas and glands in normocalcemic hyperparathyroidism: a light microscopic study. Am J Pathol 1976;83(3):475-84.

12. Dekker A, Dunsford HA, Geyer SJ. The normal parathyroid gland at autopsy: the significance of stromal fat in adult patients. J Pathol 1979;128(3):127-32.

13. Dufour DR, Wilkerson SY. The normal parathyroid revisited: percentage of stromal fat. Hum Pathol 1982;13:717-21.

14. Saffos RO, Rhatigan RM, Urgulu S. The normal parathyroid and the borderline with early hyperplasia: a light microscopic study. Histopathology 1984;8(3):407-22.

15. Panijan RP, Grbesa D, Mederal P, Jezek D, Cavcic A, Gorsic I. Do parathyroid glands from individuals of different age and gender contain lymph vessels? Coll Antropol 2006;30(2):369-73.

16. Laga EM, Driscoll SG, Munro HN. Quantitative studies of human placenta. I.Morphometry. Biol Neonate 1973;23:231-59.

17. Young B, Lowe JS, Stevens A, Heath JW. eds. Wheater's functional histology: a text and colour atlas. 5th ed. Edinburgh: Elsevier Churchill Livingstone; 2006: p.337. 